\title{
Trend and determinants of multidimensional poverty in rural Nigeria
}

\author{
ADEOTI, Adetola I. \\ Department of Agricultural Economics, University of Ibadan, Ibadan, Oyo State, Nigeria.
}

Received 19 November, 2013; Accepted 7 March, 2014

\begin{abstract}
Government continues to initiate programmes to address the challenge of poverty in Nigeria.This paper investigates the poverty levels over time using the multidimensional approach and estimates its determinants; using the National Living Standard Survey data of 2004 and 2010. The Alkire-Foster methodology and the Logit model were employed for analysis. The result showed that $70 \%$ of rural households are headed by males, are still in their economically active years and practice agriculture. Also, more than one third have no education. The adjusted headcount ratio, headcount ratio and the intensity of poverty increased in 2010 relative to 2004. The absolute and percentage change in poverty reveals that change is higher for the headcount ratio than the intensity of poverty. The health, asset and education dimensions contributed most to poverty. Agriculture has the highest adjusted poverty incidence. Being in a female headed household, increased household size, working in the agriculture sector and residing in the northern zones increase the probability of being poor. Education, working in non-agricultural sector and services, residing in South West and South East zones reduce the probability of being poor. Effort should be targeted at reducing the number of poor households; and the health, asset and education dimensions require special attention; as well as those engaged in agriculture and resident in the northern regions of the country.
\end{abstract}

Key words: Multidimensional poverty, Alkire-Foster, logit, rural Nigeria.

\section{INTRODUCTION}

The Nigerian economy has experienced substantial growth in the last decade. The real GDP growth rate rose from $2.7 \%$ in 1998 to $5.3 \%$ in 2006 and increased to $7.2 \%$ in 2011 (NBS, 2010; CIA, 2012). In spite of improvement in the country's economic growth, Nigeria suffers from high levels of poverty and it is widespread. Poverty incidence has risen over the years and was estimated to be about $69 \%$ in 2010 (NBS, 2010). The country retrogressed to become one of the 25 poorest countries at the threshold of the twenty-first century from a ranking among the richest 50 in the early-1970s. Poverty incidence was quite alarming when measured using international poverty line, which is population below $\$ 1.00$ in terms of Purchasing Power Parity PPP, and was estimated as $61.2 \%$ in 2010 . Those who live on less than $\$ 1.25$ a day was $64.41 \%$ in $2003 / 2004$ and $68 \%$ in 2010 (World Bank, 2011). In Nigeria, poverty is especially severe in rural areas where social services and infrastructure are limited (IFAD, 2012). Poverty incidence rose from 16.2 to $43.1 \%$ in the urban sector and from 
28.3 to $63.8 \%$ in the rural sector between 1980 and 2004 respectively. For over four decades in Nigeria, all attempts to put the rural areas on course of development have not been successful (Oyeranti and Olayiwola, 2005). Conditions have continued to worsen and poverty has become a major issue in the rural areas of the country in spite of its potentials and rich natural resource endowment.

The Government at various levels has continued to make efforts to transform the economy and reduce poverty. Some of these programmes include: Directorate of Food, Road and Rural Infrastructure (DFRRI), Better Life Programme (BLP), National Directorate of Employment (NDE), Agricultural Development Programme (ADP), National Agricultural Land Development Programme (NALDP), Family Support Programme (FSP), Family Economic Advancement Programme (FEAP), Poverty Eradication Programme (PEP) and National Poverty Eradication Programme (NAPEP). The latest of this is the National Economic Empowerment Development Strategy (NEEDS), State Economic Empowerment Development Strategy (SEEDS) and Local Economic Empowerment Development Strategy (LEEDS). Most of these programmes were bureaucratic and unable to effectively address the needs of the rural people.

Several studies have estimated poverty in Nigeria from the unidimensional approach (World Bank 1996; FOS, 1999; Olaniyan, 2000; Omonona, 2001; Olaniyan and Abiodun, 2005; Okunmadewa et al., 2005). Some employed multidimensional approaches (Oyekale et al., 2007; Oni and Adepoju, 2011; Ataguba et al., 2011). Few studies have also focused on rural poverty using these approaches (Oyekale et al., 2007; Oni and Adepoju, 2011; Ologbon, 2012). These studies on multidimensional poverty in rural Nigeria have employed the Fuzzy set to estimate the capabilities of rural households. While these studies have been able to identify the number of poor, it does not take into account the intensity of deprivations among the poor (Alkire and Roche, 2011); and violates dimensional monotonicity. An exception is the study by Ologbon (2012) which estimated poverty in the riverine areas using the Alkire- Foster method. Following Alkire et al. (2011) and Ologbon (2012), this study attempts to estimate rural poverty over time for the entire country; applying the Alkire- Foster method which is essentially rooted in the capability approach. This methodology will not only give the incidence and intensity of poverty but also identify deprivations driving poverty. This will inform policy makers on possible areas where interventions are required to lift the poor out of poverty.

\section{Objective}

1. Estimate the poverty status of rural households over time.

2. Identify factors that influence the poverty status of households.

\section{Measurement of poverty}

Alkire and Foster's (2007) methodology includes two steps: An identification method ( $\rho k)$ that identifies 'who is poor' by considering the range of deprivations they suffer, and an aggregation method that generates an intuitive set of poverty measures $(M \alpha)$ that can be broken down to target the poorest people and the dimensions in which they are most deprived.

The notation $y=\left[y_{i j}\right]$ denote the $n x d$ matrix of achievements, where $n$ represents the number of households, $\mathrm{d}$ is the number of dimensions, and $y_{i j} \geq 0$ is the achievement of household $i=1,2 \ldots \ldots, n$ in dimensions $j=1,2, \ldots d$. The identification method involves considering the vector $c$ of deprivation counts obtained from the deprivation cut-off, $z$ (first cut-off); which is then compared against a poverty cutoff $k$ (second cut-off) to identify the poor, where $k=1 \ldots d$.

Hence, the identification method $\rho$ is defined as $\rho_{k}\left(y_{i} ; z\right)=1$ whenever $c_{i} \geq k$, and $\rho_{k}\left(y_{i} ; z\right)=0$ whenever $c_{i}<k$. It means that a household is poor if deprived in at least $k$ number of dimensions. When $k=1$, then the identification criterion corresponds to the union approach whereas at $k=d$, the identification criterion corresponds to the intersection approach. A common alternative is to take a cutoff that lies between 1 and $d$. Finally, the set of households that are multidimensional poor is defined as $Z_{k}=\left\{i: \rho_{k}\left(y_{i} ; z\right)\right\}$. The $\rho_{k}$ is referred to as a dual cutoff method ${ }^{1}$ because it first applies the within dimension cutoff $z_{j}$ to determine which household is deprived in each dimension, and then the across dimension cutoff $k$ to determine the minimum number of deprivations suffered by an household to be considered multidimensional poor.

\section{Multidimensional poverty measure}

The headcount ratio or the percentage of households that are poor $H=H(y ; z)$ is defined by:

$H=q / n$

Where $q=q(y ; z)$ is the number of households in the set $z_{k}$, as identified using $\rho_{k}$. While it is easy to compute, it violates dimensional monotonicity in which case, if a poor household becomes deprived in an additional dimension, the headcount ratio does not change. Alkire and Foster (2007) proposed a headcount measure that is

\footnotetext{
${ }^{1}$ For detailed description of the methodology, see Alkire et al. (2011)
} 
adjusted by the average number of deprivations experienced by the poor.

In this regard, a censored vector of deprivation counts $c_{k}$ is defined so that if $c_{i} \geq k$, then $c_{i}(k)=c_{i}$; and if $c_{i}<k$, then $c_{i}(k)=0$. This means that in $c(k)$, the count of deprivations is always zero for households that are not poor, while households that were identified as poor keep the original vector of deprivation counts $c_{i}$. Then, $c_{i}(k) / d$ represents the shared possible deprivations experienced by a poor household $i$, and hence the intensity of poverty (deprivations shared across the poor) is given by:

$$
A=|c(k)| /(q d)
$$

The adjusted headcount ratio $M_{0}(y ; z)$ is given by:

$M_{0}=H A$

The adjusted headcount ratio has other properties including dimensional monotonicity, deprivation focus, poverty focus and subgroup decomposability in addition to standard properties of a poverty measure. The dimensional monotonicity implies that $A$ rises when a poor household becomes deprived in an additional dimension even though the headcount remains the same. Similar to the headcount ratio $\mathrm{H}, \mathrm{M}_{0}$ satisfies decomposability.

$\mathrm{M}_{0}$ can be decomposed by population subgroups. The decomposition is expressed as:

$M_{0}(x, y ; z)=\frac{n(x)}{n(x, y)} M_{0}(x ; z)+\frac{n(y)}{n(x, y)} M_{0}(y ; z)$

Where $x$ and $y$ corresponds to two subgroups with size $\mathrm{n}(\mathrm{x})$ and $\mathrm{n}(\mathrm{y})$ and total population size $n(x, y)$. The overall poverty is the weighted average of subgroup poverty levels, where weights are subgroup population shares.

It is also possible to break down overall multidimensional poverty measure to reveal the contribution of each dimension $\mathrm{j}$. Once the identification step has been completed, all members of the $M_{0}(y ; z)$ family can be broken down into dimension subgroups. Then, $M_{0}(y ; z)$ can be break-down into dimensional groups as:

$$
M_{0}(y ; z)=\sum_{i=1}^{n} \mu\left(g_{* j}^{0}(k)\right) / d
$$

Where $g_{* j}^{0}$ is the $\mathrm{j}$ column of the censored matrices $g^{0}(k)$. Once the identification has been applied, and the nonpoor rows of $g^{0}$ have censored to obtain $g^{0}(k)$, for each j, $\left(\mu\left(g_{* j}^{0}(k)\right) / d\right) / M_{0}(y ; z)$ can be interpreted as the post-identification contribution of dimension to overall multidimensional poverty.

\section{Changes over time}

The change in poverty over two time periods can be due to the effect of changes in the incidence of poverty or intensity of poverty or the interaction between the two (Alkire et al., 2011). This change can be assessed by considering either the absolute change across the two time periods and/or the percentage change across the two time periods. The absolute change is the difference in the level of any focal indicator across two time periods. The percentage change in poverty expresses the change relative to the initial poverty level. For two time periods $t_{x}$ and $t_{y}$ where $t_{x}$ is less than $t_{y}$ and $\mathrm{w}$ is a vector of the relative weights of the indicators; these changes are estimated as:

Annual Absolute Change in Poverty (Mo) is:

$$
\Delta M_{o}(X, Y ; z, k, w)=\frac{\left[M_{o}(Y ; z, k, w)-M_{o}(X ; z, k, w)\right]}{t_{y}-t_{x}}
$$

Annual percentage change in poverty (Mo):

$$
\delta M_{0}(X, Y ; Z, k, w)=100 \times \frac{\left[M_{0}(Y ; z, k, w)-M_{0}(X ; Z, k, w)\right]}{\left(t_{y}-t_{x}\right) M_{0}(X ; Z, k, w)}
$$

\section{METHODOLOGY}

\section{Scope of study}

Nigeria is the most populous country in Africa and the ninth most populous country in the world providing habitation for $1.9 \%$ of the world's population as at 2005 . The population of the country rose from about 88.5 million in 1991 to 140 million in 2006 (FRN, 2007) and 168.8 million in 2012 (World Bank, 2012). The study area is rural Nigeria with a population of $77,803,783$ in 2010 (World Bank, 2012). Nigeria is made up of 36 states and a Federal Capital Territory (FCT), grouped into six geopolitical zones: North Central, North East, North West, South East, South South and South West.

\section{Source and type of data}

The study uses secondary data comprising mainly of the National Living Standard Survey (NLSS) data in 2004 and 2010. The NLSS survey data is a national representative data and provides data on household's socio-economic and demographic data. The data used in this paper are age, gender, marital status, primary occupation, household size, educational attainment and geo-political zones. Others are household's type of dwelling, floor material, wall material, roof material, fuel for cooking, source of lighting, toilet type and source of drinking water. In addition, data on if household head ever attended school or has at least six years of formal education, any member suffer any form of illness or activities stopped due to illness, household asset ownership and land ownership were obtained. 
Table 1. Dimensions, indicators, deprivation cutoffs and weights of MPI.

\begin{tabular}{|c|c|c|}
\hline Dimension (Weight) & Indicator (Weight) & Deprivation cut-off \\
\hline Housing (1/5) & $\begin{array}{l}\text { Type of dwelling }(1 / 30) \\
\text { Floor material }(1 / 30) \\
\text { Wall material }(1 / 30) \\
\text { Roof material }(1 / 30) \\
\text { Fuel for cooking }(1 / 30) \\
\text { Source of lighting }(1 / 30)\end{array}$ & $\begin{array}{l}\text { Households living in a single room, house with no flooring (that } \\
\text { is, a mud or dung floor) or inadequate roofing and wall material. } \\
\text { (United Nations, 2003). Households using firewood, coal as } \\
\text { main source of cooking fuel and those without electricity, solar } \\
\text { and other improved sources as main lighting material. }\end{array}$ \\
\hline Sanitation (1/5) & $\begin{array}{l}\text { Toilet type }(1 / 10) \\
\text { Source of drinking water }(1 / 10)\end{array}$ & $\begin{array}{l}\text { Households using unimproved sanitation facilities such as pit } \\
\text { latrine without slab, open pit latrine, bucket toilet and hanging } \\
\text { toilet(United Nations, 2003), and households using water from } \\
\text { an unimproved source such as open wells, open springs or } \\
\text { surface water. (United Nations, 2003) }\end{array}$ \\
\hline Education (1/5) & $\begin{array}{l}\text { Ever attended school }(1 / 10) \\
\text { Household head with at least six years } \\
\text { of formal education. }(1 / 10)\end{array}$ & $\begin{array}{l}\text { Household head that has not attended any form of schooling } \\
\text { and households without household head having at least } 6 \text { years } \\
\text { of formal education. (United Nations, 2003). }\end{array}$ \\
\hline Health $(1 / 5)$ & $\begin{array}{l}\text { Suffer any form of illness }(1 / 10) \\
\text { Activities stopped due to illness. }(1 / 10)\end{array}$ & $\begin{array}{l}\text { Household heads that suffer from any form of illness and } \\
\text { stopped activities as a result of such illness }\end{array}$ \\
\hline Assets (1/5) & $\begin{array}{l}\text { Asset ownership }(1 / 10) \\
\text { Land ownership }(1 / 10)\end{array}$ & $\begin{array}{l}\text { The household does not own more than one of the following } \\
\text { assets: bicycle, radio, telephone, television, a house and does } \\
\text { not own agricultural land }\end{array}$ \\
\hline
\end{tabular}

\section{Analytical technique}

The Alkire-Foster methodology explained under the measurement section is used to estimate the multidimensional poverty. The dimensions and indicators considered are listed in Table 1.

\section{Dimensions and cut-offs}

The determinants of poverty are estimated using the logit model. The model is specified as:

$z_{i}=b_{0}+\sum_{j=1}^{k} b_{k} x_{i j}+\varepsilon_{i}$

$Z_{i}$ is the poverty status of the $i^{\text {th }}$ household represented with a dummy; 1 if poor and 0 otherwise. $j=1,2, \ldots \ldots . k$ are the vectors of the predictor variables explaining poverty $b_{0}, b_{k}$ are the parameters to be estimated while $\varepsilon_{k}$ is the error term.

The predictor variables X, are: Gender of household head, age of household head, marital status, primary occupation of household head, educational attainment of household head, Household size and geo-political zones.

\section{RESULTS AND DISCUSSION}

\section{Socio-demographic characteristics}

Table 2 presents the socio-demographic characteristics of households. The patterns of distribution of sociodemographic characteristics of households are similar in the years considered (2004 and 2010). The male household heads represent $86 \%$ of all households in both years. This agrees with the pattern of household headship in Nigeria. Aigbokhan (2000) reported a similar result with only $13.5 \%$ of household heads being female. Similarly, the heads of households are mostly within ages 20 and 59 years representing $76.8 \%$ in 2004 and $73.7 \%$ in 2010 . This means that they are still in their economically active years which enables them engage in diverse means of livelihood. Households with sizes between 4 to 6 persons represent about $40 \%$ in each year; followed by those with 7 to 9 persons. Only a quarter has household sizes of seven and above which means that most of the households are not excessively large in size. Over $60 \%$ had no education in 2004 but it reduced in 2010 to $44.8 \%$. However, much of the reduction is due to increase among those with primary education in 2010. Although, the reduction is large but over one-third still have no education. There is need for increased literacy among household heads and also access to education beyond primary level. Agriculture remains the primary occupation for about $70 \%$ of rural households. This agrees with the description of the rural sector as mostly an agrarian society as stated by Okunmadewa (2002).

\section{Household poverty estimates}

The multidimensional poverty estimates are based on five dimensions: Housing, sanitation, education, health and assets as shown in Table 1; with equal weights assigned to all. For each dimension, thresholds were set which is 
Table 2. Socio economic Characteristics of Rural Households.

\begin{tabular}{|c|c|c|c|c|}
\hline Category & $\begin{array}{c}2004 \\
\text { Frequency }\end{array}$ & Percentage & $\begin{array}{c}2010 \\
\text { Frequency }\end{array}$ & Percentage \\
\hline \multicolumn{5}{|l|}{ Gender } \\
\hline Male & 12552 & 86.5 & 21624 & 86.7 \\
\hline Female & 1960 & 13.5 & 3317 & 13.3 \\
\hline \multicolumn{5}{|l|}{ Age(years) } \\
\hline $0-19$ & 36 & 0.2 & 109 & 0.4 \\
\hline $20-39$ & 4552 & 31.4 & 8202 & 32.9 \\
\hline $40-59$ & 6585 & 45.4 & 10180 & 40.8 \\
\hline$>=60$ & 3339 & 23.0 & 6450 & 25.9 \\
\hline \multicolumn{5}{|l|}{ Marital status } \\
\hline Married & 11529 & 79.4 & 21641 & 86.8 \\
\hline Divorced & 557 & 3.8 & 706 & 2.8 \\
\hline Widowed & 1660 & 11.4 & 2593 & 10.4 \\
\hline Never married & 766 & 5.3 & 1 & 0.0 \\
\hline \multicolumn{5}{|l|}{ Household size } \\
\hline $1-3$ & 4948 & 34.1 & 9321 & 37.4 \\
\hline 4-6 & 6147 & 42.4 & 10076 & 40.4 \\
\hline $7-9$ & 2450 & 16.9 & 4237 & 17.0 \\
\hline 10 and above & 967 & 6.7 & 1307 & 5.2 \\
\hline \multicolumn{5}{|c|}{ Educational attainment } \\
\hline No education & 9252 & 63.8 & 11184 & 44.8 \\
\hline Primary education & 2837 & 19.5 & 7853 & 31.5 \\
\hline Secondary education & 1575 & 10.9 & 3890 & 15.6 \\
\hline Tertiary education & 848 & 5.8 & 2014 & 8.1 \\
\hline \multicolumn{5}{|l|}{ Primary occupation } \\
\hline Agriculture & 11132 & 76.7 & 17444 & 69.9 \\
\hline Services & 1109 & 7.6 & 3889 & 15.6 \\
\hline Non agriculture & 2271 & 15.6 & 3608 & 14.5 \\
\hline \multicolumn{5}{|l|}{ Region } \\
\hline North Central & 2751 & 19.0 & 4217 & 16.9 \\
\hline North East & 2732 & 18.8 & 4338 & 17.4 \\
\hline North West & 3122 & 21.5 & 6869 & 27.5 \\
\hline South East & 2351 & 16.2 & 3583 & 14.4 \\
\hline South South & 2363 & 16.3 & 3860 & 15.5 \\
\hline \multirow[t]{2}{*}{ South West } & 1193 & 8.2 & 2074 & 8.3 \\
\hline & $N=14512$ & & $\mathrm{~N}=24941$ & \\
\hline
\end{tabular}

the first cutoff; to identify if the household is deprived in that dimension. A second cutoff, $\mathrm{k}$ was set which states the number of dimensions in which a household can bedeprived to be considered MPI poor.

Table 3 presents the estimated poverty indices based on different cut-offs, $\mathrm{k}$. It can be observed from the table that from 2004 to 2010 , the headcount and the adjusted headcount ratio decreased with increase in $\mathrm{k}$. This agrees with the findings of Batana (2008). With the number of deprivations experienced by the households at $\mathrm{K}$ equals 1 , the head count ratio $\mathrm{H}$ is about $100 \%$. This shows that there is no household that is not deprived in at least one 
Table 3. Household multidimensional poverty indices.

\begin{tabular}{ccccccc}
\hline \multirow{2}{*}{$\mathbf{K}$} & $\mathbf{2 0 0 4}$ & \multicolumn{5}{c}{$\mathbf{2 0 1 0}$} \\
\cline { 2 - 7 } & $\mathbf{M}_{\mathbf{0}}=\mathbf{H A}$ & $\mathbf{H}$ & $\mathbf{A}$ & $\mathbf{M}_{\mathbf{0}}=\mathbf{H A}$ & $\mathbf{H}$ & $\mathbf{A}$ \\
\hline 1 & 0.566 & 0.997 & 0.568 & 0.646 & 0.999 & 0.647 \\
2 & 0.552 & 0.927 & 0.595 & 0.640 & 0.970 & 0.660 \\
3 & 0.427 & 0.615 & 0.694 & 0.553 & 0.750 & 0.735 \\
4 & 0.210 & 0.252 & 0.833 & 0.342 & 0.400 & 0.855 \\
5 & 0.040 & 0.040 & 1.000 & 0.108 & 0.108 & 1.000 \\
\hline
\end{tabular}

Table 4. Changes in MPI, headcount ratio and intensity of poverty at $\mathrm{K}=3$.

\begin{tabular}{|c|c|c|c|c|c|c|}
\hline & \multicolumn{2}{|c|}{$M_{0}$} & \multicolumn{2}{|c|}{ H } & \multicolumn{2}{|c|}{ A } \\
\hline Year & 2004 & 2010 & 2004 & 2010 & 2004 & 2010 \\
\hline & 0.427 & 0.553 & 0.615 & 0.750 & 0.694 & 0.735 \\
\hline Annual absolute change & \multicolumn{2}{|c|}{0.021} & \multicolumn{2}{|c|}{0.022} & \multicolumn{2}{|c|}{0.006} \\
\hline Annual percent change & \multicolumn{2}{|c|}{4.92} & \multicolumn{2}{|c|}{3.65} & \multicolumn{2}{|c|}{0.984} \\
\hline
\end{tabular}

Table 5. Relative contributions of dimensions to $\mathrm{MPI}$ at $\mathrm{K}=3$.

\begin{tabular}{cccccc}
\hline Year & $\begin{array}{c}\text { Housing } \\
\text { contribution (\%) }\end{array}$ & $\begin{array}{c}\text { Sanitation } \\
\text { contribution (\%) }\end{array}$ & $\begin{array}{c}\text { Education } \\
\text { contribution (\%) }\end{array}$ & $\begin{array}{c}\text { Health } \\
\text { contribution (\%) }\end{array}$ & $\begin{array}{c}\text { Assets } \\
\text { contribution (\%) }\end{array}$ \\
\hline 2004 & 13.56 & 17.13 & 19.43 & 27.49 & 22.39 \\
2010 & 13.87 & 16.77 & 20.59 & 25.87 & 22.90 \\
\hline
\end{tabular}

dimension. At $k=3,61.5 \%$ are estimated poor in 2004 but this increased to $75 \%$ by 2010 ; similarly, the adjusted headcount ratio increased in 2010 . However, the intensity of poverty increases with increase in $\mathrm{K}$, that is, the share of dimensions in which the poor are deprived increases with $\mathrm{K}$. Although, the multidimensional household poverty index is decreasing with increase in $\mathrm{K}$, it is because the number of households that are poor is reducing but the intensity of poverty among the poor is increasing.

Following Alkire and Roche (2011), poverty estimates at $\mathrm{K}=3$ over time were compared and all the poverty measures reveal an increase in their estimates. This means that poverty is increasing and is due to both increase in headcount, $\mathrm{H}$ (a change in the percentage of people who are poor) and the intensity, A (a change in the share of deprivations in which the poor are deprived) of poverty among the poor. The adjusted headcount increased from 0.427 in 2004 to 0.553 in 2010.

The annual absolute change and percent change in poverty reveals that the change is higher for the headcount ratio than the intensity of poverty as shown in Table 4. Alkire et al, (2011) posited that in Lesotho, Kenya and Nigeria, change in MPI is achieved by reduction in headcount and barely by reduction in intensity of poverty. This implies that while the country increases effort to reduce the intensity of poverty, greater effort should be made to get people out of poverty

The relative contribution of dimensions to poverty is shown in Table 5 . The pattern in both years is the same and it reveals that health contributed most to poverty followed by asset and education. The contribution of health to poverty reduced in 2010 relative to 2004; but the opposite was the case for education. In spite of this, it is imperative to tackle rural poverty by giving attention to these priority areas as International Fund for Agriculture Development, IFAD (2001) emphasized that increasing access to assets. They defined assets to include education, health, land, and housing and considered it crucial for broad-based growth and poverty reduction.

\section{Change in poverty indices by geopolitical zones (GPZ)}

The change in poverty indices over time by GPZ is shown in Table 6. Arranging in order of decreasing poverty is North West, North East, North Central, South East, South South and South West. North West records the highest poverty rate and the annual percentage change in all the indices. It also records an increase in poverty from 2004 to 2010. However, North East has the highest intensity of 
Table 6. Changes in MPI, headcount ratio and intensity of poverty at K=3 by GPZ.

\begin{tabular}{lcccc}
\hline Geo-political zones & Year & $\mathbf{M}_{\mathbf{0}}$ & $\mathbf{H}$ & $\mathbf{A}$ \\
\hline North Central & 2004 & 0.170 & 0.173 & 0.983 \\
Annual absolute change & 2010 & 0.182 & 0.181 & 1.006 \\
Annual percentage change & & 0.002 & 0.001 & 0.004 \\
North East & & 1.176 & 0.771 & 0.389 \\
& 2004 & 0.205 & 0.192 & 1.068 \\
Annual absolute change & 2010 & 0.216 & 0.212 & 1.019 \\
Annual percentage change & & 0.0018 & 0.003 & -0.008 \\
North West & & 0.894 & 1.736 & -0.765 \\
& 2004 & 0.259 & 0.268 & 0.966 \\
Annual absolute change & 2010 & 0.292 & 0.295 & 0.990 \\
Annual percentage change & & 0.0555 & 0.0045 & 0.004 \\
South East & & 2.124 & 1.679 & 0.414 \\
Annual absolute change & 2004 & 0.170 & 0.173 & 0.983 \\
Annual percentage change & 2010 & 0.118 & 0.122 & 0.967 \\
South South & & -0.0086 & -0.0085 & -0.0026 \\
Annual absolute change & & -5.098 & -4.913 & -0.271 \\
Annual percentage change & 2004 & 0.162 & 0.157 & 1.032 \\
South West & 2010 & 0.139 & 0.136 & 1.022 \\
Annual absolute change & & -0.0038 & -0.0035 & -0.0016 \\
Annual percentage change & 2004 & -2.366 & -2.229 & -0.161 \\
\hline
\end{tabular}

poverty though it reduced in 2010. The North West and North East are worst affected by poverty in the country. Studies have reported that northern regions of the country have high poverty levels relative to the southern regions (Odusola, 1997; Okunmadewa et al., 2005; NBS, 2009). Over time, in the South East and South South, the headcount and the intensity reduced. The South East recorded the highest annual percentage reduction in poverty. Although, the South West is the least poor, there is still increase in incidence. This means that the interventions in the zone have not impacted positively to reduce poverty in the zone, although there is a decline in intensity.

\section{Decomposition by gender}

In Table 7, poverty indices increased for both gender over time. While more female headed households were poor in 2004; equal number was poor in 2010. This reflects that a higher proportion of male headed households became poor in 2010. The annual percentage change in headcount and intensity increased for male headed households but only the percentage change in headcount increased for female headed households. In all, irrespective of gender, there is annual percentage increase in headcount and adjusted headcount ratio. However, the percentage change in the intensity of poverty reduced for female and is estimated as -0.179 .

\section{Decomposition by occupation}

With respect to occupation, poverty was highest among those engaged in agriculture, followed by services and lastly by those engaged in Non-agriculture related occupation in both 2004 and 2010. In Agriculture, poverty incidence was very high at 0.663 in 2010 . Southgate et al. (2007) asserted that the impact of the household head being primarily involved in agriculture is linked with high poverty rates, hunger, and malnutrition and also recent analysis of poverty has shown that poverty is disproportionately concentrated among households whose primary livelihood lie in agricultural activities (Federal 
Table 7. Changes in MPI, Headcount Ratio and Intensity of Poverty at K = 3 .

\begin{tabular}{lcccc}
\hline Variable & Year & $\mathbf{M}_{\mathbf{0}}$ & $\mathbf{H}$ & $\mathbf{A}$ \\
\hline Occupation & & & & \\
Agriculture & 2004 & 0.628 & 0.739 & 0.985 \\
& 2010 & 0.663 & 0.671 & 0.988 \\
Annual absolute change & & 0.006 & -0.011 & 0.003 \\
Annual percentage change & & 0.928 & -1.533 & 0.051 \\
Non-agriculture & 2004 & 0.156 & 0.148 & 1.057 \\
& 2010 & 0.166 & 0.161 & 1.031 \\
Annual absolute change & & 0.002 & 0.002 & -0.004 \\
Annual percentage change & & 1.068 & 1.464 & -0.409 \\
Services & 2004 & 0.196 & 0.186 & 1.054 \\
& 2010 & 0.171 & 0.168 & 1.018 \\
Annual absolute change & & -0.004 & -0.003 & -0.006 \\
Annual percentage change & & -2.126 & -1.613 & -0.569 \\
Gender & & & & \\
Male & 2004 & 0.408 & 0.618 & 0.660 \\
& 2010 & 0.553 & 0.751 & 0.736 \\
Annual absolute change & & 0.024 & 0.022 & 0.013 \\
Annual percentage change & & 5.923 & 3.587 & 1.919 \\
Female & 2004 & 0.429 & 0.579 & 0.741 \\
Annual absolute change & 2010 & 0.553 & 0.754 & 0.733 \\
Annual percentage change & & 0.021 & 0.029 & -0.001 \\
\hline
\end{tabular}

Republic of Nigeria, 2007). In a similar finding, Amao and Awoyemi (2009) reported an inverse relationship between non-agriculture activities and poverty. Nonetheless, agriculture recorded a decrease in annual percentage change in headcount $(-1.53)$ but the intensity of poverty increased (0.05). More attention must target reducing intensity of poverty while enhancing effort to continue to reduce its incidence. This shows that if poverty is reduced substantially in the agricultural sector, rural poverty will fall since over half of rural households are engaged in the agricultural sector. This contrasts the situation for those in services where both the incidence and intensity is reducing over time. It should be noted that the intensity of poverty for those in services and non-agriculture is higher than those in agriculture; therefore intervention should be made to further reduce these intensities.

\section{Determinants of household poverty in rural Nigeria}

\section{Multivariate analysis}

Table 8 shows the Logit regression estimates of the determinants of household poverty. The MPI obtained for poverty cut-off $(k)$ equals three $(0.427$ in 2004 and 0.553 in 2010) was taken as the poverty line to classify households into poor and non- poor. Results from the analysis of logistic regression model shows that the chi square value is significant at $1 \%$ level which confirms that the model is a good fit for the data.

The factors that increase the probability of being poor are female headed households, household heads that are more than 60years old, household sizes that are four or more, households in north-west, north-east, south-south and year 2010. Those that decrease the probability of being poor are having household heads between ages 20 and 59 years, being practitioners in the non-agriculture or services sector, having household head that have no education or belonging to south west and south east geopolitical political zone.

Households headed by females have a higher probability of being poor. A female headed household increases the likelihood of being poor by 0.019 and is significant at $1 \%$. Similar findings have been reported by Apata et al. (2010), Bastos et al. (2009) and World Bank (1999). The presence of discrimination against women in the labour market, or that women tend to have lower education than men and hence they are paid lower salaries as opined by Bastos et al. (2009). Also, females are not as privileged as their male counterparts in terms of asset ownership and accumulation (World Bank, 2001; 
Table 8. Determinants of household poverty in rural Nigeria.

\begin{tabular}{|c|c|c|}
\hline Predictor variables & Coefficients & Marginal effects \\
\hline \multicolumn{3}{|c|}{ Gender of household head } \\
\hline Male & $0.0819^{*}$ & $0.0199^{*}$ \\
\hline Female & $(0.0490)$ & $(0.0118)$ \\
\hline \multicolumn{3}{|c|}{ Age of household head (years) } \\
\hline $0-19$ & 1 & 1 \\
\hline $20-39$ & $-0.0890^{* * *}(0.0182)$ & $-0.0218^{* * *}(0.0459)$ \\
\hline $40-59$ & $-0.0574^{\star * *}(0.0100)$ & $-0.0141^{\star * *}(0.0459)$ \\
\hline$>=60$ & $0.0025^{* *}(0.0011)$ & $0.0006^{* *}(0.0460)$ \\
\hline \multicolumn{3}{|l|}{ Marital status } \\
\hline Not Married & 1 & 1 \\
\hline Married & $-0.0611(0.0890)$ & $-0.0149(0.0216)$ \\
\hline Divorced & $0.1164(0.1089)$ & $0.0282(0.0261)$ \\
\hline Widowed & $-0.0518(0.1007)$ & $-0.0127(0.0248)$ \\
\hline \multicolumn{3}{|l|}{ Household size } \\
\hline $1-3$ & 1 & 1 \\
\hline $4-6$ & $0.1591^{* * *}(0.0277)$ & $0.0390^{* * *}(0.0068)$ \\
\hline $7-9$ & $0.2000^{* * *}(0.0362)$ & $0.0493^{* * *}(0.0089)$ \\
\hline$>9$ & $0.2159^{* * *}(0.0532)$ & $0.0534^{* * *}(0.0133)$ \\
\hline \multicolumn{3}{|l|}{ Primary occupation } \\
\hline Agric. related & 1 & 1 \\
\hline Non-agriculture & $-0.6128^{\star * *}(0.0327)$ & $-0.1518^{* * *}(0.0080)$ \\
\hline Services & $-0.4666^{* * *}(0.0358)$ & $-0.1157^{* \star *}(0.0089)$ \\
\hline \multicolumn{3}{|l|}{ Educational level } \\
\hline No education & 1 & 1 \\
\hline Primary education & $-1.1159^{* * *}(0.0264)$ & $-0.2718^{* * *}(0.0061)$ \\
\hline Secondary education & $-1.9482^{* * *}(0.0352)$ & $-0.4368^{* * *}(0.0060)$ \\
\hline Tertiary education & $-2.7548^{* * *}(0.0559)$ & $-0.5261^{\star \star *}(0.0054)$ \\
\hline \multicolumn{3}{|l|}{ Geo-political zone } \\
\hline North Central & 1 & 1 \\
\hline North East & $0.2936^{* * *}(0.0395)$ & $0.0706^{\star * \star}(0.0089)$ \\
\hline North West & $0.0562^{*}(0.0351)$ & $0.0137^{*}(0.0085)$ \\
\hline South East & $-0.0877^{*}(0.0407)$ & $-0.2157^{*}(0.0100)$ \\
\hline South South & $0.2094^{* * *}(0.0046)$ & $0.0516^{\star * \star}(0.0096)$ \\
\hline South West & $-0.1261^{* * *}(0.0482)$ & $-0.0310^{* * *}(0.0119)$ \\
\hline \multicolumn{3}{|l|}{ Year } \\
\hline 2010 & $0.3843^{* * *}(0.0252)$ & $0.0944^{* * *}(0.0061)$ \\
\hline Constant & $1.1254^{* * *}(0.2000)$ & \\
\hline Number of observations & 39,453 & \\
\hline $\operatorname{LR} \operatorname{chi}^{2}(21)$ & 7691.35 & \\
\hline Log likelihood & -23126.895 & \\
\hline Prob $>c h i^{2}$ & 0.0000 & \\
\hline Pseudo $\mathrm{R}^{2}$ & 0.1426 & \\
\hline
\end{tabular}

${ }^{* * *} P<0.01{ }^{* *} P<0.05{ }^{*} P<0.1$; 'Standard errors in parenthesis.

Olorunsanya, 2009). Such differential access to productive asset and inputs leads to inequality in welfare.
Consequently female headed households continue to suffer in poverty. 
Being between the ages of 20 to 59 years reduces the probability of being poor relative to the base category of 0 to 19 years; while being above 60 years increases the probability of being poor. The marginal effect estimates show that the greatest reduction in the probability of being poor is between ages 20 and 39 years. The marginal effect of the age group 20 to 39 years is -0.022 , indicating that a change in age category from the base category ( 0 to 19 years) to 20 to 39 years category significantly reduce poverty by 0.022 . Studies carried out in Nigeria by Nzenwa and Oboh (2005), Olubanjo et al. (2007) reported that age of household head had a positive effect on poverty. Babatunde et al. (2008) also posited that prevalence of poverty is higher among the older age group. These studies show that it is difficult to make a general conclusion on the effect of the age of household head. However, this study shows that while increase in age reduces probability of being poor initially, at a threshold, it increases it.

Generally, large household size reduces welfare in most regions of the country. The larger the household size, the poorer the household. Results show that household size had positive correlation with the probability of a household being poor for household sizes from four and the coefficients are significant at $1 \%$. The marginal effect increases with increased household sizes. The estimates are $0.0390,0.0493$ and 0.0534 for households with sizes of 4 to 6 persons, 7 to 9 persons and greater than 9 persons, respectively. Thus, household poverty increases with increasing size of the household. This position is consistent with Omonona (2010) who posited that large household size are associated with poverty and Lipton (1999) also maintained that small households are less likely to be poor than others. Also, similar findings were reported by Schoummaker (2004), Aassve et al. (2005), Kates and Dasgupta (2007). The absence of welldeveloped social security systems and low savings in developing countries (especially those in Africa) tends to increase fertility rates, particularly among the poor, in order for the parents to have some economic support from children when parents reach old age. This is one of the rationales for parents to increase the number of children as children serve as a form of informal insurance for their parents when old.

Relative to agriculture, other occupations reduce the probability of being poor. The marginal effects for nonagricultural activities ${ }^{2}$ and services are -0.1518 and 0.1157 , respectively. This implies that non-agricultural activities have the highest probability of reducing poverty followed by services. This position is similar to the findings of Anyanwu (2010) that occupation has a high correlation with poverty in Nigeria. Also, past studies have also identified that most of the poorest households in Sub

\footnotetext{
${ }^{2}$ Non-agricultural activities are paid government employment, international and local cooperatives, private employers, parastatals, NGOs. Services are mainly artisans.
}

Saharan Africa are found working in agriculture (Ikpi, 1989; Ayoola et al., 2000; Okunmadewa, 2002; Spencer, 2002; Alayande and Alayande, 2004; Poulton et al., 2005; Apata, 2006).

Education significantly decreases the probability of being poor. The estimated marginal effects reveal that the likelihood of being poor is further reduced also by increasing levels of education. Apata et al. (2010) and Palmer-Jones and Sen (2003) reported same result for rural South-west Nigeria and India respectively.

Anyanwu (2012) emphasized the importance of regional location in explaining poverty in rural Nigeria. The North East, North West and South South geo-political zones of the country has a statistically significant positive effect on the probability of being poor relative to the North Central zone. On the contrary, the results show that South West and the South East zones decrease the probability of being poor. The marginal effect estimates are 0.0706, 0.0516 and 0.0137 for North East, South South and North West respectively which shows that households in the North East have the highest probability of increasing poverty. Also, households in the South East and South West decrease the probability of being in poverty with estimated marginal effects of 0.2157 and 0.03 respectively. There is an increase in the probability of being poor in 2010 relative to 2004 which means that there is an increase in the probability of becoming poor over time.

\section{Conclusion}

Households are mostly male headed and over $70 \%$ of rural households are in their economically active years. Although, there is reduction in the number of household heads without education, over one-third are still without any form of education. Household sizes are moderate with only a quarter with more than seven persons. Agriculture remains the primary occupation in rural households. The adjusted headcount ratio, headcount ratio and intensity of poverty increased in 2010 relative to 2004 . The absolute change and percentage change in poverty reveals that the change is higher for the headcount ratio than the intensity of poverty. The health, asset and education dimension contributed most to poverty. Both the headcount and the intensity of poverty increased for male headed households while only the headcount increased for women. Agriculture has the highest adjusted poverty incidence in both years, but the incidence reduced in 2010 while the intensity remained high. The significant factors that increase the probability of being poor are being a female headed household, increased household size, working in the agriculture sector, residing in North West, North East and South South geo-political zones. The significant factors that decrease the probability of being poor are working in non-agricultural sector and services, having education, residing in South West and South East geo-political zones. 
This implies that programmes should be targeted to reducing the number of poor rural households. Targeted programmes in health and education dimensions will reduce poverty substantially. Improving asset of rural households can be achieved by improving access to resources and enforcing policies that define rights to these resources. Educational training should go beyond the primary level. The agricultural sector requires more attention to reduce poverty in the sector. Particularly rural households in Northern Nigeria and South South geopolitical zones require more attention to bring them out of poverty.

\section{Conflict of Interests}

The author(s) have not declared any conflict of interests.

\section{REFERENCES}

Aassve A, Engelhardt H, Francavilla F, Kedir A, Kim J, Mealli $F$, Mencarini L, Pudney S, Prskawetz A (2005). Poverty and Fertility in Less Developing Countries: A comparative Analysis, ISER Working Paper 2005-2013.

Aigbokhan BE (2000). Poverty, growth and inequality in Nigeria: A case study. African Economic Research Consortium (AERC) Research Paper 102. Nairobi: African Economic Research Consortium.

Alayande B, Alayande O (2004). A Quantitative and Qualitative Assessment of Vulnerability to Poverty in Nigeria. A Paper submitted for presentation of CSAE Conference on Poverty reduction, Growth and Human Development in Africa, March, 2004.

Alkire S, Foster's JE (2007). Counting and Multidimensional Poverty Measurement. Oxford Poverty and Human Development Initiative, OPHI Working Paper 7.

Alkire S, Roche JM, Santos ME, Seth S (2011). Multidimensional Index 2011. Brief Methodological Note. Oxford Poverty and Human Development Initiative.

Amao JO, Awoyemi TT (2009). Determinants of Adoption of Improved Rice Varieties and its Impacts on Farmers Poverty Level in Iwo Agricultural Development Programme of Osun State. Niger. J. Rural Sociol. 9(1):1-8.

Anyanwu JC (2010). Poverty in Nigeria: A Gendered Analysis. Afr. Stat. J. 11:38-61.

Anyanwu JC (2012). Accounting for Poverty in Africa: Illustration with Survey Data from Nigeria. African Development Bank Group. Working P. 149

Apata TG (2006). Income and Livelihood Diversification Strategies of Farming Households in Crude-oil Polluted Areas of Ondo State, Nigeria. Unpublished PhD Thesis in the Department of Agricultural Economics, University of Ibadan, Nigeria.

Apata TG, Apata OM, Igbalajobi OA, Awoniyi SMO (2010). Determinants of Rural Poverty in Nigeria: Evidence from small holder farmers in South-western, Nigeria. J. Sci. Tech. Edu. Res. 1(4):85-91. http://www.academicjournals.org/JSTER.

Ataguba J, Fonta WM, Ichoku HE (2011). The Determinants of Multidimensional poverty in Nsukka, Nigeria. PMMA Working Paper, 2011-2013. Poverty and Economic Policy Research Network.

Ayoola GB, Aina B, Mamman N, Nweze T, Odebiyi F, Okunmadewa D, Shehu O, Williams, Zasha J (2000). NIGERIA: Voice of the Poor Country Synthesis Report World Bank.

Babatunde RO, Olorunsanya EO, Adejola AD (2008). Assessment of rural household poverty: Evidence from South Western Nigeria. AmEur. J. Agric. Environ. Sci. 3(6):900-905.

Bastos A, Casaca SF, Nunes F, Pereirinha J (2009). Women and Poverty: A Gender-Sensitive Approach. J. Socio-Econ. 38(5):764-78. http://dx.doi.org/10.1016/j.socec.2009.03.008
Batana $Y$ (2008). Multidimensional Measurement of poverty in SubSaharan Africa. OPHI Working Paper 13. Oxford University: Oxford Poverty and Human Development Initiative.

CIA (2012). Data for Nigeria from CIA World Factbook.

Federal Office of Statistics (FOS) (1999). Poverty Profile for Nigeria, 1980-1996, Lagos.

Federal Republic of Nigeria (FRN) (2007). Legal notice on publication of 2006 census results. Federal Republic of Nigeria Official Gazette 94(4).

IFAD (International Fund for Agricultural Development) (2001). The Rural Poverty Report. International Fund for Agricultural Development, Rome, Italy. www.ifad.org/poverty/index.htm.

IFAD (International Fund for Agricultural Development) (2012). Enabling poor rural people to overcome poverty in Nigeria. The Rural Poverty Report. Rome, Italy.

Ikpi AE (1989). Understanding the Nigerian Rural Farmer for Effective Adoption of Improved Agricultural Technology and Impact Modelling. IITA Research Monograph, Ibadan, Nigeria P. 4.

Kates RW, Dasgupta P (2007). African Poverty: A Grand Challenge for Sustainability Science, PNAS, 104(43):16747-16750. http://dx.doi.org/10.1073/pnas.0708566104

Lipton M (1999). Growing Points in Poverty research: International Institute for Labour. 6(16):5-10.

National Bureau of Statistics (NBS) (2009). (www.nigerianstat.gov.ng).

National Bureau of Statistics (NBS). (2010). The Nigeria Poverty Profile 2010 Report, National Bureau of Statistics, Abuja.

Nzenwa GC, Oboh VU (2005). Effects of Household Endowments on Poverty among farmers in Benue State. Proceedings of 39th Conference of the Agricultural Society of Nigeria, University of Benin. Nigeria October $9-13^{\text {th }}:$ pp. 308-311.

Odusola AF (1997). Poverty in Nigeria: An Eclectic Appraisal. Selected Papers from the Nigerian Economic Society's Annual Conference.

Okunmadewa F (2002). Poverty and Agricultural Sector in Nigeria. In Okunmadewa: Elshaddai (Ed): Poverty Reduction and Agricultural Sector in Nigeria. Ibadan. Global ventures LTD.

Okunmadewa FY, Yusuf SA, Omonona BT (2005). Social Capital And Poverty Reduction in Nigeria, Revised Report Submitted To Africa Economic Research Consortium (AERC) Nairobi, Kenya.

Olaniyan O (2000). The role of household endowments in determining poverty in Nigeria. www.csae.ox.ac.uk/conferences/2000OiA/pdfpapers/olaniyan-95.PDF.

Olaniyan O, Abiodun S (2005). Human capital, capabilities and poverty in rural Nigeria Research Report submitted to the African Economic Research Consortium (AERC), for the Second Phase Collaborative Poverty Research Project. Nairobi: African Economic Research Consortium

Ologbon O (2012). Welfare Deprivation and Multidimensional Poverty among Riverine Households in South-western Nigeria. Unpublished $\mathrm{PhD}$ Thesis, University of Ibadan. Ibadan, Nigeria.

Olorunsanya EO (2009). Gender of Household heads and Relative Poverty Among Rural Farming Households in Kwara State, Nigeria.

Olubanjo OO, Akinleye SO, Soremekun WA (2007). Poverty determinants among farmers in Ogun State, Nigeria. Medwell Agric. J. 2(2):275-280.

Omonona BT (2001). Poverty and its correlates among Rural Farming Households in Kogi State, Nigeria. Ph.D. Thesis, University of Ibadan, Ibadan, Nigeria.

Omonona BT (2010). Quantitative analysis of rural poverty in Nigeria. The Nigeria Strategy Support Program (NSSP) of the International Food Policy Research Institute IFPRI, Brief P. 17.

Oni OA, Adepoju TA (2011). A capability approach to the analysis of rural households' Wellbeing in Nigeria. MPRA P. 34508.

Oyekale TO, Okunmadewa FY, Omonona BT, Oni OA (2007). fuzzy set approach to multidimensional poverty decomposition in rural Nigeria. Department of Agricultural Economics, University of Ibadan, Ibadan, Nigeria.

Oyeranti O, Olayiwola K (2005). Policies and programmes for poverty reduction in rural Nigeria. An Interim Research Report Submitted to the African Economic Research Consortium (AERC), Nairobi for the Second Phase Collaborative Poverty Research Project.

Palmer-Jones R, Sen K (2003). What Has Luck Got to Do With It? A Regional Analysis of Poverty and Agricultural Growth in Rural India. J. 
Dev.

Stud.

http://dx.doi.org/10.1080/00220380412331293647

Poulton C, Dorward A, Kydd J (2005). The future of small farms: New Directions for Services, Institutions and Intermediation. In Proceedings of Research Workshop on the future of small farms Wye, Uk Organised by International Food policy Research Institute (IFPRI)/2020 initiative and Overseas Development Institute (ODI) Imperial College, London.

Schoummaker B (2004). Poverty and fertility in sub-Saharan Africa: Evidence from 25 countries.

Southgate D, Graham D, Tweeten L (2007). The World Food Economy. Blackwell: Oxford.

Spencer D (2002). The future of Agriculture in Sub-Saharan Africa and South Asia. In Sustainable Food Security for All by 2020. Proceedings of an International Conference, September 4-6, 2001, Bonn, Germany. International Food Policy Research Institute, Washington, D.C.

United Nations (2003). Indicators for Monitoring Millennium Development Goals. New York: United Nations.
World Bank (1996). Nigeria: poverty in the midst of plenty, the challenge of growth with inclusion. A World Bank Poverty Assessment, Population and Human Resources Division Report 1473. Washington, DC: World Bank.

World Bank (1999). Participatory Poverty Assessment Report. Washington, DC. World Bank: pp. 5-20.

World Bank (2011). World Development Indicators 2011. World Bank, Washington DC.

World Bank (2012). An update to the World Bank's estimates of Consumption Poverty in the Developing World.

World Bank (2001). Bangladesh Poverty Assessment: Background Paper on Poverty Trends, Dhaka, World Bank. 